\title{
Prevalence and Risk Factors of Malnutrition among HIV-Infected Children Aged 2-18 Years: A Cross-Sectional Study
}

\author{
Visal Moolasart*, Suthat Chottanapund, Jarurnsook Ausavapipit and Somtavil Ampornareekul
}

Bamrasnaradura Infectious Diseases Institute, Ministry of Public Health, Nonthaburi, Thailand

*Corresponding author: Visal Moolasart, Bamrasnaradura Infectious Diseases Institute, Ministry of Public Health, Nonthaburi, Thailand, Tel: +66-2590 3408; Fax: +66-2590 3411; E-mail: vismool@yahoo.com

Received date: January 05, 2017; Accepted date: February 04, 2017; Published date: February 10, 2017

Citation: Moolasart V, Chottanapund S, Ausavapipit J, Ampornareekul S (2017) Prevalence and Risk Factors of Malnutrition among HIV-Infected Children Aged 2-18 Years: A Cross-Sectional Study. Pediatric Infect Dis 2:36. doi: 10.21767/2573-0282.100036

Copyright: (C) 2017 Moolasart V, et al. This is an open-access article distributed under the terms of the Creative Commons Attribution License, which permits unrestricted use, distribution, and reproduction in any medium, provided the original author and source are credited.

\section{Abstract}

Background: Malnutrition and underweightness are common problems among HIV-infected children in low and middle income countries.

Methods and findings: A single-centered, retrospective, cross-sectional cohort survey was conducted between January 1, 2014 and June 30, 2014 to assess the prevalence and risk factors of malnutrition among HIV-infected children aged 2-18 years at the Bamrasnaradura Infectious Diseases Institute (BIDI), Thailand. Clinical and laboratory data were compared between a malnutrition group, (Group A): body mass index (BMI) for age $<5^{\text {th }}$ percentile and a nonmalnutrition group (Group B): BMI-for-age $>5^{\text {th }}$ percentile and $<95^{\text {th }}$ percentile. One hundred and ninety-five HIVinfected children were retained for analyses. The prevalence of malnutrition was $43 \%$ (83 of 195). The following proportions were higher in Group A than B, respectively: advanced clinical staging ( $83 \%$ vs. $12 \%)$, PI-based HAART ( $73 \%$ vs. $38 \%$ ) and anaemia ( $48 \%$ vs. $8 \%$ ) (all $p<0.05)$. The median of Log10 plasma HIV RNA was higher in Group A than $B(1.7$ vs. 1.6, respectively; $p<0.05)$. The proportions of RNA $\leq 40$ copies $/ \mathrm{mL}$ and parent caregivers in Group A were lower than B ( $48 \%$ vs. $86 \%$ and $35 \%$ vs. $54 \%$, respectively; all $\mathrm{p}<0.05)$. Other factors did not differ significantly. In multivariate analysis, malnutrition was significantly associated severity (WHO stages 3 and 4) (OR=184.50, 95\% $\mathrm{Cl}=[35.72-952.73]), \mathrm{PI}(\mathrm{OR}=5.38,95 \% \mathrm{Cl}=[1.97-14.67])$ and parent as caregivers $(\mathrm{OR}=0.56,95 \% \mathrm{Cl}=[0.34-0.92])$. No significant differences between Group $A$ and $B$ were found in $\log _{10}$ plasma HIV RNA, RNA $\leq 40$ copies $/ \mathrm{mL}$, hemoglobin and anemia.

Conclusion: The prevalence of malnutrition was $43 \%$. Malnutrition among HIV-infected children was associated with the severity of disease, PI-based HAART and nonparent caregiver.

\section{Keywords: Malnutrition, Body mass index, HIV-infected} children

\section{Introduction}

Malnutrition is estimated to contribute to more than 20 million childhood morbidity and mortality [1]. Weight loss and undernutrition are common in people living with HIV/AIDS, likely accelerating disease progression, increasing morbidity and reducing survival [2]. HIV and malnutrition are common comorbidities in low and middle income countries [3]. An African study demonstrated a prevalence of malnutrition among HIV-infected children of $42 \%$ [4]. The nutritional statuses of children living with HIV/AIDS are affected by frequent or persistent diarrhoea, pneumonia and tuberculosis (TB) [3]. In HIV/AIDS patients, malnutritional deficiencies and medical conditions are the major causes of morbidity and mortality [5-8]. Malnutritional worsens HIV disease by damaging lymphoid tissues and decreasing CD4 T-cell concentration, both of which weaken the immune system, especially in HIV-infected children [9]. Moreover, malnutrition leads to irreversible cognitive impairment, chronic diseases and growth failure [10].

In research and practice, a body mass index (BMI) cut-off of $18.5 \mathrm{~kg} / \mathrm{m}^{2}$ is used to identify malnutrition or underweightness in adults living with HIV [11,12]. Malnutrition or underweightness in children is defined as a BMI-for-age $<5^{\text {th }}$ percentile at 2-18 years old [13]. Malnutrition and underweightness among HIV-infected children have been associated with greater risk of hospitalization, loss to follow-up (LTFU), TB, drug interaction, severe disease and anaemia [14-18]. In Malawi, acute malnutrition (26.6\%) was the most common primary admission diagnosis, especially for HIVinfected children less than 3 years old and associated with longer admission [19]. The linkages between HIV/AIDS and malnutrition are many, strong and long-lasting through a vicious cycle of immune dysfunction, infectious disease and malnutrition [20]. TB is a most deadly infectious disease. A variety of causes increase susceptibility to Mycobacterium tuberculosis infection such as HIV/AIDS, malnutrition, very young age and drug [21]. Several studies have demonstrated the prevalence of anemia among HIV-1 infected children, which varies from 16 to $94 \%$. This increases with advancing stage of HIV disease, but varies with sex, age, as well as the definition of anemia used [22-24]. In a meta-analysis of over 2000 HIV- 
infected children, the prevalences of mild ( $\mathrm{Hb} 10-12.0 \mathrm{gm} / \mathrm{dL})$ and moderate anemia $(\mathrm{Hb} 8.0-9.9 \mathrm{gm} / \mathrm{dL}$ ) were $22 \%-94 \%$ and $3 \%-82 \%$, respectively [25]. In Mozambique, there was $68 \%$ malnutrition and 51\% WHO clinical stages 3 or 4 among all HIVinfected children under 15 years old [4]. Weight loss is associated with the progression of HIV infection, but it is unclear whether it causes progression or is a disease severity marker [26]. Distance from clinic causes LTFU, affecting disease severity. In Cameroon, retention in care was associated with good access to care and was defined as living $\leq 40 \mathrm{~km}$ of the clinic site [27].

The data of malnutrition or underweightness important for management are limited. Therefore, we evaluated the prevalence and risk factors of malnutrition among $\mathrm{HIV}^{-}$infected children 2-18 years old at the Bamrasnaradura Infectious Diseases Institute (BIDI), Thailand.

\section{Methods}

\section{Study design}

We conducted a retrospective, cross-sectional cohort survey of HIV-infected children seen at the BIDI, Thailand between January 1, 2014 and June 30, 2014. Participants were HIVinfected children aged 2-18 years with confirmed HIV-infection by a positive serological test. Children were excluded for missing data, no antiretroviral drug and a follow-up period $\leq 6$ months. The primary objective was the prevalence of malnutrition .The secondary objective was identification of the factors associated with the malnutrition group (Group $A$ ) and non-malnutrition group (Group B). Group A was defined as BMI-for-age $<5^{\text {th }}$ percentile and Group B as BMI for age $>5^{\text {th }}$ percentile and $<95^{\text {th }}$ percentile. We extracted all laboratory and clinical data, including established age, sex, weight, height, BMI, history of household TB contact, previous TB disease, adherence, disclosure or non-disclosure, WHO clinical staging, receipt of highly active antiretroviral therapy (HAART), CD4 cell counts, HIV RNA level, $\mathrm{Hb}$, anaemia, cholesterol, triglyceride, death, study status, distance of residence and caregiver. All data were obtained from medical records at the first visit. Results of CD4, viral load and other laboratory tests were collected during survey. All children had vertical transmission.

$\mathrm{BMI}$ is the weight of a person in kilograms divided by the square of the height in meters. BMI for children and teenagers is age and sex-specific and is often referred to as BMI-for-age (2-18 years old). The BMI-for-age percentile growths charts are the most commonly used measures of size and growth patterns in children and teenagers. Malnutrition and underweightness were defined as a BMI for age $<5^{\text {th }}$ percentile [13].

The WHO clinical staging of HIV disease in children, adolescents and adults was developed in 1990 and revised in 2007. Staging is based on clinical findings that guide the diagnosis, evaluation and management of HIV/AIDS. Clinical stages are categorized as 1 through 4, progressing from primary HIV infection to advanced HIV/AIDS [28]. Anemia was defined as a HB level of $<5^{\text {th }}$ percentile for age [29]. Short and long distances of residence were defined as living $\leq 40 \mathrm{~km}$ and $>40$ $\mathrm{km}$ from the study centre, respectively [27].

\section{HIV testing}

Children over 18 months old were tested by serology only, which classified children as infected or uninfected. Children under 18 months old were also initially tested serologically. Afterwards positive and negative samples from HIV-exposed children were tested for DNA by PCR on dried blood spots. Those PCR detected viral DNA were classified as infected, and those PCR was negative were classified as uninfected.

\section{Study population and sample size calculation}

All continuous data were compared with the Student's t-test and the Mann-Whitney $U$ test. Categorical data were compared with the chi-square test. A $p$-value of $<0.05$ was considered statistically significant. A multinomial regression model studied the factors associated with malnutrition. All variables with $p$ value $<0.05$ in bivariate analyses were selected for multivariate analyses. Factors considered were age, sex, history household TB contact, previous TB disease, a proportion of adherence $\geq 95 \%$, disclosure, WHO clinical staging, the proportion of protease inhibitor (PI)-based HAART, CD4 cell counts, HIV RNA level, a proportion of RNA $\leq 40$ copies/mL, $\mathrm{Hb}$, anaemia, cholesterol, triglyceride, death, study status, distance of residence and caregiver during survey. In BIDI, the majority of HIV infected children are adolescents. Therefore, the sample size was calculated by a proportional formula assuming prevalence of malnutrition of $22.2 \%$ among HIV infected children [30], the calculated minimum sample size for the malnutrition group was 67.

The study protocol was reviewed and approved by Institutional Review Board of Bamrasnaradura Infections Diseases Institute, Ministry of Public Health, Thailand.

\section{Results}

\section{Study population}

Figure 1 shows a flow chart of the enrolment. Two hundred and eight children were enrolled. Thirteen (6\%) were excluded: 7 follow-up for less than 6 months, 3 overweight and 3 no antiretroviral drug. One hundred and ninety-five were included in the final analysis. Of these, 83 (43\%) were malnutrition or underweightness (Group A) and 112 (57\%) were nonmalnutrition (Group B).

Table 1 displays the demographics and characteristics of participants. The majority were male in Group A but female in $B$. The mean ages of Group A and B were 14.56 and 13.64 years, respectively. Sex and age of both groups were not significantly different $(p<0.05)$.

\section{Clinical and laboratory risk factors of study children}

The risk factors of the participants are shown in Table 2. The following proportions were higher in Group $A$ than in B, respectively: advanced clinical staging (83 vs. 12\%), PI-based HAART ( $73 \%$ vs. $38 \%$ ) and anaemia ( $48 \%$ vs. $8 \%$ ) (all $p<0.05)$. The median of Log10 plasma HIV RNA was higher in Group A than $B(1.7$ vs. 1.6 , respectively; $p<0.05)$. The proportions of RNA 
$\leq 40$ copies $/ \mathrm{mL}$ and parent caregivers in Group A were lower than B (48\% vs. $86 \%$, respectively and $35 \%$ vs. $54 \%$, respectively; all $(p<0.05)$. No significant differences between Group A and B were found in history household TB contact, previous TB disease, the proportion of adherence $\geq 95 \%$, mean CD4 levels, cholesterol, triglyceride, death, study status and distance of residence (all $p>0.05$ ).

Factors associated with malnutrition are shown in Table 3. In multivariate analysis, malnutrition was significantly associated with HIV disease severity (WHO stages 3 and 4) (OR=184.50, $95 \% \mathrm{Cl}=[35.72-952.73]), \mathrm{Pl}(\mathrm{OR}=5.38,95 \% \mathrm{Cl}=[1.97-14.67])$ and parent caregivers $(\mathrm{OR}=0.56,95 \% \mathrm{Cl}=[0.34-0.92])$. No significant differences between Group $A$ and $B$ were found in $\log _{10}$ plasma HIV RNA, RNA $\leq 40$ copies/mL, $\mathrm{Hb}$ and anemia (all $\mathrm{p}>0.05$ ).

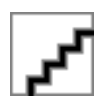

Figure 1: Enrolment and follow-up of study children.

Table 1: Demographics and characteristics of study children.

\begin{tabular}{|l|l|l|l|}
\hline & Group A & Group B & \multirow{2}{*}{$\begin{array}{c}\text { p- } \\
\text { value }\end{array}$} \\
\hline Factor & Malnutrition & Non-malnutrition & \\
\hline Sex, $\mathrm{n}$ & $\mathrm{n}=83$ & $\mathrm{n}=112$ & \\
\hline Male & & 51 & 0.11 \\
\hline Female & 48 & 61 & \\
\hline Age, $\mathrm{y}$ & 35 & & \\
\hline Mean \pm SD & $14.56 \pm 3.36$ & $13.64 \pm 7.11$ & 0.27 \\
\hline
\end{tabular}

Table 2: Clinical and laboratory factors of study children.

\begin{tabular}{|c|c|c|c|}
\hline \multirow{3}{*}{ Factor } & Group A & Group B & \multirow{3}{*}{ p-value } \\
\hline & Malnutrition & $\begin{array}{l}\text { Non- } \\
\text { malnutrition }\end{array}$ & \\
\hline & $n=83$ & $n=112$ & \\
\hline $\begin{array}{l}\text { History household TB } \\
\text { contact, } \mathrm{n}(\%)\end{array}$ & $17(20)$ & $16(14)$ & 0.334 \\
\hline $\begin{array}{l}\text { Previous TB disease, } n \\
(\%)\end{array}$ & $6(7)$ & $12(11)$ & 0.46 \\
\hline Adherence $\geq 95 \%, \mathrm{n}(\%)$ & $68(82)$ & $93(83)$ & 0.697 \\
\hline Disclosure, n (\%) & $65(78)$ & $79(71)$ & 0.251 \\
\hline \multicolumn{3}{|l|}{ WHO stage, n (\%) } & \multirow{3}{*}{0.00} \\
\hline 1,2 & $14(17)$ & $99(88)$ & \\
\hline 3,4 & $69(83)$ & $13(12)$ & \\
\hline \multicolumn{3}{|l|}{ HAART, n (\%) } & \multirow{3}{*}{0.00} \\
\hline $\mathrm{PI}$ & $61(73)$ & $42(38)$ & \\
\hline Non PI & $22(27)$ & $70(62)$ & \\
\hline
\end{tabular}

\begin{tabular}{|c|c|c|c|}
\hline $\begin{array}{l}\text { CD } 4 \text { cell count, mean } \pm \\
\text { SD (cell/ } / \mu \mathrm{L})\end{array}$ & $725 \pm 442$ & $783 \pm 484$ & 0.462 \\
\hline \multirow{2}{*}{$\begin{array}{l}\text { Log10 plasma HIV RNA, } \\
\text { median (range) }\end{array}$} & 1.7 & 1.6 & \multirow{2}{*}{0.041} \\
\hline & $(1.3-6.0)$ & $(1.3-5.33)$ & \\
\hline $\begin{array}{l}\text { RNA } \leq 40 \text { copies } / \mathrm{mL}, \mathrm{n} \\
(\%)\end{array}$ & $40(48)$ & $96(86)$ & 0.00 \\
\hline $\begin{array}{l}\text { Hemoglobin, mean } \pm S D \text {, } \\
\text { (g/dl) }\end{array}$ & $11.70 \pm 1.31$ & $12.37 \pm 1.30$ & 0.02 \\
\hline Anemia, $\mathrm{n}(\%)$ & $40(48)$ & $9(8)$ & 0.00 \\
\hline $\begin{array}{l}\text { Cholesterol, mean } \pm \text { SD } \\
(\mathrm{mg} / \mathrm{dl})\end{array}$ & $178.89 \pm 50.49$ & $190.96 \pm 43.15$ & 0.135 \\
\hline $\begin{array}{l}\text { Triglyceride, mean } \pm \text { SD } \\
(\mathrm{mg} / \mathrm{dl})\end{array}$ & $\begin{array}{l}156.58 \\
106.05\end{array} \quad \pm$ & $145.76 \pm 70.65$ & 0.44 \\
\hline Death, n (\%) & $8(10)$ & $5(4)$ & 0.245 \\
\hline \multicolumn{3}{|l|}{ Study status, n (\%) } & \multirow{3}{*}{0.194} \\
\hline Yes & $64(77)$ & $95(85)$ & \\
\hline No & $19(23)$ & $17(15)$ & \\
\hline \multicolumn{3}{|l|}{$\begin{array}{l}\text { Distance of residence, } \mathrm{n} \\
(\%)\end{array}$} & \multirow{3}{*}{0.068} \\
\hline Short & $72(87)$ & $85(76)$ & \\
\hline Long & $11(13)$ & $27(24)$ & \\
\hline \multicolumn{3}{|l|}{ Caregiver, n (\%) } & \multirow{4}{*}{0.01} \\
\hline Parent & $29(35)$ & $60(54)$ & \\
\hline Relatives & $33(40)$ & $39(35)$ & \\
\hline Care center & $21(25)$ & $13(11)$ & \\
\hline
\end{tabular}

Table 3: Associations between malnutrition and factors, along with multivariate multinomial logistic regressions.

\begin{tabular}{|l|l|l|l|}
\hline Significant factors & Odds ratio & p-value & $\mathbf{9 5 \%} \mathbf{C l}$ \\
\hline WHO stage & 184.5 & 0.00 & $35.72-952.73$ \\
\hline $\mathrm{PI}$ & 5.38 & 0.001 & $1.97-14.67$ \\
\hline Caregiver & 0.56 & 0.023 & $0.34-0.92$ \\
\hline Log $_{10}$ plasma HIV RNA & 1.014 & 0.975 & $0.41-2.47$ \\
\hline RNA $\leq 40$ copies/mL & 0.57 & 0.187 & $0.24-1.32$ \\
\hline Hemoglobin (g/dl) & 1.06 & 0.33 & $0.94-1.21$ \\
\hline Anemia, $\mathrm{n}(\%)$ & 1.33 & 0.663 & $0.37-4.75$ \\
\hline
\end{tabular}

\section{Discussion}

We have demonstrated a prevalence of malnutrition as high as $43 \%$ among $\mathrm{HIV}^{-}$infected children. This finding is similar to a previous study. It demonstrated prevalences of malnutrition among HIV-infected children in central and West Africa aged 5-10 years and aged $10-19$ years were 36 and $44 \%$, respectively [4]. In contrast, a previous study in adolescents living with HIV/ AIDS showed a prevalence of malnutrition as low as 9.9\% [31]. Nevertheless, studies are difficult to compare due to the differences in study populations, study designs and definitions of 
malnutrition. We have found that malnutrition among HIVinfected children was associated with the HIV/AIDS disease severity (advanced WHO clinical stagings), PI-based HAART and non- parent caregiver. The risk of malnutrition in HIV infection increases, because high pro-inflammatory cytokine activity can cause growth impairment among children [32]. Children or adolescents living with HIV/AIDS may acquire many infections that are conducive to malnutrition, underweightness, morbidity and mortality. Malnutrition also worsens HIV disease due to lymphoid-tissues breakdown and decreased CD4 T-cell concentration $[4,9]$. It is noteworthy that $83 \%$ of malnourished children in the present study were classified as WHO clinical stages 3 or 4 because BIDI is a HIV referral center. This contrasts to a previous study in which only $30 \%$ of malnourished children were WHO clinical stages 3 or 4 [3]. We found PI-based HAART was associated with malnutrition because $\mathrm{PI}$ is a second line drug regimen in Thailand, which is related to advanced stages of HIV disease.

We have demonstrated a low the proportion of parent as caregiver was associated with malnutrition, which is similar to other previous studies among HIV-infected children in subSaharan Africa [33-35]. In contrast, a previous study demonstrated that the proportions of parent caregivers or orphan status were not associated with malnutrition [4].

In our study, no significant differences between Group $A$ and $B$ were found in sex, age, history household TB contact, previous TB disease, the proportion of adherence $\geq 95 \%$, disclosure, mean CD4 levels, cholesterol, triglyceride, death, study status and distance of residence (all $p>0.05$ ). In multivariate analysis, no significant differences between Group $A$ and $B$ were found in Log10 plasma HIV RNA, RNA $\leq 40$ copies/mL, $\mathrm{Hb}$ and anemia (all $p>0.05)$. However, a previous study demonstrated that boys were more likely to be malnourished than girls. The reasons for this association between gender and malnutrition remain unclear and need further study [4,36]. In Kenya, a further association between distance of residence and LTFU was report [37]. This may be related to severity of disease and malnutrition. However, we have found distance of residence did not affect malnutrition, which was similar to the finding of a Kansas City study in the USA [38]. Several studies have reported anaemia was associated with advancing stage of HIV disease [22-24]. The most important cause of anemia in HIV- infected children is insufficient production of erythrocytes caused by ineffective erythropoiesis, reduced erythropoietin production, associated infections, neoplasia, medications, and micronutrient deficiencies [39].

Our study has several limitations. Firstly, the study was a retrospective cross-sectional cohort study and short duration survey. Some data are missing such as timing from onset of diagnosis to initiating HAART, protein calorie malnutrition and data of LTFU along with the levels of macronutrients, trace minerals and microelements. Secondly, the sample size was small and possibly unrepresentative of the population of children living with HIV/AIDS in Thailand. Children included in our study were only those accessing the pediatric HIV service at BIDI, a referral centre. We had to exclude children less than 2 years old because we could not evaluate malnutrition or underweightness by BMI-for-age.

\section{Conclusion}

In conclusion, the prevalence of malnutrition among HIV infected children aged 2-18 years was $43 \%$. Malnutrition among HIV-infected children was associated with the severity of disease, PI-based HAART and non-parent caregiver.

\section{Acknowledgements}

We thank all the study participants and staff of Bamrasnaradura Infectious Diseases Institute, Ministry of Public Health, Nonthaburi, Thailand.

\section{Ethics approval}

The study protocal was reviewed and approved by Institutional Review Board of Bamrasnaradura Infections Diseases Institute, Ministry of Public Health, Thailand. The reference approval letter number is SO12h/58 and 11/55-562.

\section{Funding}

The authors have no affiliation with or involvement in any organization or entity that has a financial interest in the subject matter or materials discussed in this manuscript.

\section{References}

1. Black RE, Allen LH, Bhutta ZA (2008) Maternal and child undernutrition: global and regional exposures and health consequences. Lancet 371: 243-260.

2. Swaminathan S, Padmapriyadarsini C, Sukumar B (2008) Nutritional status of persons with HIV infection, persons with HIV infection and tuberculosis and HIV-negative individuals from southern India. Clin Inf Dis 46: 946-949.

3. Amadi B, Imikendu M, Sakala M, Banda R, Kelly P (2016) Integration of HIV Care into Community Management of Acute Childhood Malnutrition Permits Good Outcomes: Retrospective Analysis of Three Years of a Programme in Lusaka. PLoS One 4: 11.

4. Jesson J, Masson D, Adonon A (2015) Growing Up Working Group. Prevalence of malnutrition among HIV-infected children in Central and West-African HIV-care programmes supported by the Growing up Programme in 2011: a cross-sectional study. BMC Infect Dis $15: 216$

5. Polo Rodríguez R (2002) Manual de nutrition y SIDA, 3rd Edn. Madrid: Welcome.

6. Fenton M, Silverman E (2005) Terapia nutricional para a doença do vírus da imunodeficiência humana. In:Mahan L, Escott-Stump S, organizadores. Krause-alimentos, nutrição \& dietoterapia. 11a Ed. São Paulo: Roca; pp 980-1010.

7. Kotler DP (2000) Nutritional alterations associated with HIV infection. J Acquir Immune Defic Syndr 1: 81-87.

8. Salomon JTPD, De Truchis P, Melchior JC (2002) Nutrition and HIV infection. Br J Nutr 1: 111-119. 
9. Cunningham-Rundles S, McNeeley DF, Moon A (2005) Mechanisms of nutrient modulation of the immune response. J Allergy Clin Immunol 115: 1119-1128.

10. Victora CG, Adair L, Fall C (2008) Maternal and child undernutrition: consequences for adult health and human capital. Lancet 371: 340-357.

11. Sicotte M, Bemeur C, Diouf A, Zunzunegui MV, Nguyen VK (2015) Nutritional status of HIV-infected patients during the first year HAART in two West African cohorts. J Health Popul Nutr 34: 1.

12. WHO (1995) "Physical status: the use and interpretation of anthropometry. Report of a WHO Expert Committee" World Health Organ Tech Rep Ser 854: 1-452.

13. http://www.cdc.gov/healthyweight/assessing/bmi/ childrens_bmi/about_childrens_bmi.html

14. Feucht UD, van Bruwaene L, Becker PJ, Kruger M (2016) Growth in HIV-infected children on long-term antiretroviral therapy. Trop Med Int Health 23.

15. Congdon M, Gjelsvik A, Lurie MN (2015) The Role of Nutritional Status on Follow-up among HIV-infected Children at a Teaching Hospital Clinic in Ghana. West Afr J Med 34: 20-26

16. Ribera E, Pou L, Lopez RM (2001) Pharmacokinetic interaction between nevirapine and rifampicin in HIV-infected patients with tuberculosis. J Acquir Immune Defic Syndr 28: 450-453.

17. Ren Y, Nuttall JJ, Egbers C (2008) Effect of rifampicin on lopinavir pharmacokinetics in HIV-infected children with tuberculosis. J Acquir Immune Defic Syndr 47: 566-569.

18. Shet A, Bhavani PK, Kumarasamy N (2015) Anemia, diet and therapeutic iron among children living with HIV: a prospective cohort study. BMC Pediatr 15: 164.

19. Nosek CA, Buck WC, Caviness AC (2016) Hospital admissions from a pediatric HIV care and treatment program in Malawi. BMC Pediatr 16: 22.

20. Sicotte M, Langlois ÉV, Aho J, Ziegler D, Zunzunegui MV (2014) Association between nutritional status and the immune response in HIV+ patients under HAART: protocol for a systematic review. Syst Rev. 2014 Feb 3: 9.

21. Kumari P, Meena LS (2014) Factors affecting susceptibility to Mycobacterium tuberculosis: a close view of immunological defence mechanism. Appl Biochem Biotechnol 174: 2663-2673.

22. Consolini R, Benviclli W, Legitimo A (2007) Pre HAART follow- up study of the hematological manifestation in children with prenatal HIV infection, suggestions for reclassification of clinical disease. Italian register for HIV infection in children. Paediatri. Hematol Oncol 29: 376-383.

23. Adetifa IM, Temiye EO, Akinsulie AO, Ezeaka VC, Iroha EO (2006) Hematological abnormalities associated with paediatric HIV/AIDS in Lagos. Ann Trop Paediatr 26: 121-125.
24. Totin D, Ndugwa C, Mmiro F (2002) Iron deficiency anemia is highly prevalent among HIV infected and uninfected infants in Uganda American Society of nutritional sciences. J Nutri 132: 423-429.

25. Calis JC, van Hensbroek MB, de Haan RJ (2008) HIV-associated anemia in children: systemic review from global perspective. AIDS 22: 1099-1112.

26. Wheeler DA (1999) Weight loss and disease progression in HIV infection. AIDS Read 9: 347.

27. Mosoko JJ, Akam W, Weidle P (2007) Survival and adherence to ART in an era of decreasing drug cost in Limbe, Cameroon. 14th Conference on Retroviruses and Opportunistic Infections; pp 536-536.

28. www.who.int/hiv/pub/guidelines/hivs. tagig150307.pdf, 2007

29. http://www.aafp.org/afp/2010/0615/p1462.html\#sec-2

30. Sunguya BF, Poudel KC, Otsuka K (2011) Undernutrition among HIV-positive children in Dar es Salaam, Tanzania: antiretroviral therapy alone is not enough. BMC Public Health 11: 869.

31. Tanaka LF, Latorre Mdo R, Silva AM (2015) High prevalence of physical inactivity among adolescents living with HIV/Aids. Rev Paul Pediatr 33: 327-332.

32. Johann-Liang R, O'Neill L, Cervia J (2000) Energy balance, viral burden, insulin-like growth factor-1, interleukin-6 and growth impairment in children infected with human immunodeficiency virus. AIDS 14: 683-690.

33. Magadi MA (2011) Household and community HIV/AIDS status and child malnutrition in sub-Saharan Africa: evidence from the demographic and health surveys. Soc Sci Med 73: 436-446.

34. Sarker M, Neckermann C, Müller O (2005) Assessing the health status of young AIDS and other orphans in Kampala, Uganda. Trop Med Int Health 10: 210-215.

35. Zidron AM, Juma E, Ice GH (2009) Does being an orphan decrease the nutritional status of Luo children? Am J Hum Biol 21: 844-451.

36. Muenchhoff M, Goulder PJ (2014) Sex differences in pediatric infectious diseases. J Infect Dis 3: 120-126.

37. Ochieng V, Ochieng D, Sidle J (2008) Gender and loss-to follow-up (LTFU) from a large HIV treatment program in Western Kenya. Paper presented at: XVII International AIDS Conference.

38. Rao K, Gantt T, McField, Dean S, Griffin R (2010) Non-Engagement in HIV Care. Paper presented at: Infectious Diseases Society of America 48th Annual Meeting; Vancouver.

39. Kibaru EG, Nduati R, Wamalwa D, Kariuki N (2015) Impact of highly active antiretroviral therapy on hematological indices among HIV-1 infected children at Kenyatta National Hospital-Kenya: retrospective study. AIDS Res Ther 2015 12: 26. 